\title{
Evolution of a lateral dike intrusion revealed by relatively-relocated dike-induced earthquakes: the 2014-15 Bárðarbunga-Holuhraun rifting event, Iceland
}

\author{
Jennifer Woods ${ }^{\mathrm{a}, *}$, Tom Winder ${ }^{\mathrm{a}}$, Robert S. White ${ }^{\mathrm{a}}$, Bryndís Brandsdóttir ${ }^{\mathrm{b}}$ \\ ${ }^{a}$ University of Cambridge, Department of Earth Sciences, Bullard Laboratories, Cambridge, \\ $U K$ \\ ${ }^{b}$ Institute of Earth Sciences, University of Iceland, Reykjavik, Iceland
}

\begin{abstract}
Understanding dikes is vital as they serve both as bodies that build the crust and as conduits that feed eruptions, and must be monitored to evaluate volcanic hazard. During the 2014-15 Bárðarbunga rifting event, Iceland, intense seismicity accompanied the intrusion of a $\sim 50 \mathrm{~km}$ lateral dike which culminated in a 6 month long eruption. We here present relocations of earthquakes induced by the lateral dike intrusion, using cross-correlated, sub-sample relative travel times. The $\sim 100 \mathrm{~m}$ spatial resolution achieved reveals the complexity of the dike propagation pathway and dynamics (jerky, segmented), and allows us to address the precise relationship between the dike and seismicity, with direct implications for hazard monitoring. The spatio-temporal characteristics of the induced seismicity can be directly linked in the first instance to propagation of the tip and opening of the dike, and following this - after dike opening - indicate a relationship with magma pressure changes (i.e. dike inflation/deflation), followed by a general 'post-opening' decay. Seismicity occurs only at the base of the dike, where dike-imposed stresses - combined with the background tectonic stress (from regional extension over $>200$ years since last rifting) - are sufficient to induce failure of pre-existing weaknesses in the crust, while the greatest opening is at shallower depths. Emplacement oblique to the spreading ridge resulted in left-lateral shear motion along the distal dike section (studied here), and a prevalence of left-lateral shear failure. Fault plane strikes are predominately independent of the orientation of lineations delineated by the hypocenters, indicating that they are controlled by the underlying host rock fabric. This high-resolution study provides unprecedented opportunity for comparison with both geodetic and field (frozen dike) observations, and development and consolidation of analytical and analogue models, with implications for rifting processes and real-time monitoring of magma intrusion.
\end{abstract}

\footnotetext{
${ }^{*}$ Corresponding author

Email address: jw845@cam.ac.uk (Jennifer Woods)
} 
Keywords: Bárðarbunga, dike intrusion, microseismicity, cross-correlation, rifting, induced earthquakes

\section{Introduction}

Dike intrusions are usually accompanied by microseismicity, but to what extent, and precisely where this seismicity occurs in relation to the magma itself, remains unclear. Migrating seismicity is widely reported to mark the tip of a propagating dike (e.g. 1975-1984 Krafla rifting episode, Iceland, Einarsson and Brandsdóttir, 1980; Brandsdóttir and Einarsson, 1979; 1998 Izu Peninsula dike intrusion, Japan, Hayashi and Morita, 2003; Morita et al., 2006), therefore playing a key role in hazard monitoring. However, seismicity often does not reflect the full extent of a dike, and the amount of seismicity produced varies significantly on a case by case basis (Rubin et al. 1998, \& references therein).

Microseismicity is not only the principal geophysical observable for tracking intrusions in near real-time, but it is also key to advancing our understanding of the physical mechanisms of dike intrusion. Geodetic observations provide constraints on dike emplacement, but resolution is often too limited in space (particularly depth) and/or time (in the case of InSAR) to extract smaller-scale details. Similarly, field observations of frozen dikes, or of syn-emplacement surface features (e.g. fractures, grabens), offer some information but are ultimately restricted by minimal exposure. Extensive modeling, both numerical and with analogue experiments, has been carried out to assess the factors and conditions controlling dike propagation (see Rivalta et al., 2015, for a full review), but until recently we have lacked high-precision observations to corroborate these models. With improvements in instrument networks and processing techniques, seismic observations now give very high resolution spatial and temporal information, alongside moment release and focal mechanisms, providing detailed insights into the mechanisms of dike intrusion.

We here present precise, relative relocations of microseismicity associated with the 2014 lateral dike intrusion from Bárðarbunga volcano, Iceland, revealing complexity of the dike propagation pathway and dynamics. The intrusion was extensively monitored and there exist many studies - e.g. geodetic inversions (Sigmundsson et al., 2015; Spaans and Hooper, 2018), studies of ice cauldron, surface fracturing and graben formation (Reynolds et al., 2017; Hjartardóttir et al., 2016; Ruch et al., 2016; Rossi et al., 2016) - that can aid our interpretation and understanding of the overall process. The seismicity was recorded in such detail that we are also able to begin to address questions about the precise relationship between the dike and seismicity, with direct implications for hazard monitoring. 


\subsection{The 2014-2015 Bárðarbunga rifting event}

The Bárðarbunga volcanic system is one of several major hotspot-related volcanic systems at the junction of Iceland's Eastern and Northern Volcanic Zones, where plate spreading is occurring at $\sim 18.5 \mathrm{~mm}$ per year (DeMets et al., 2010). The system comprises a central volcano, located beneath Vatnajökull glacier, and a $\sim 200 \mathrm{~km}$ long transecting fissure swarm. Situated close to both the spreading ridge axis and above the Iceland hotspot, it is one of Iceland's most active volcanoes, with known eruptions including caldera, flank and fissure swarm eruptions to both the northeast and the southwest (Thordarson and Larsen, 2007). Whilst the last confirmed eruption prior to 2014 was less than 20 years previously (the 1996 sub-glacial Gjálp eruption, Gudmundsson et al., 1997), no known rifting has taken place along the northeastern fissure swarm since the early 18th century, causing a $\sim 4 \mathrm{~m}$ extension deficit in the brittle upper crust (Hartley and Thordarson, 2013; Ruch et al., 2016).

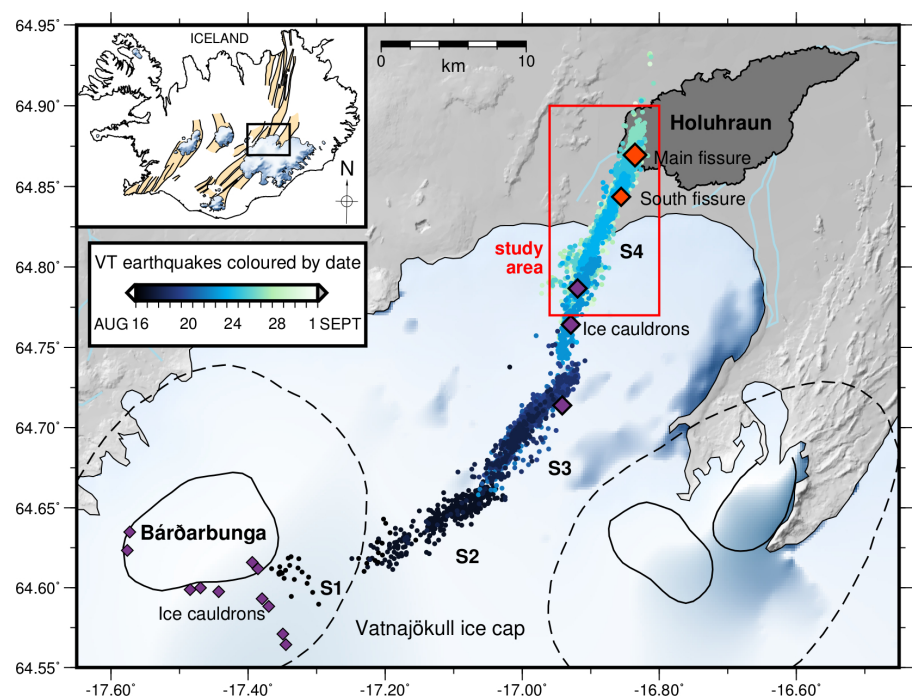

Figure 1: Location and overview of the 2014-15 Bárðarbunga-Holuhraun rifting event. Volcano-tectonic (VT) earthquakes associated with dike propagation colored by date (from Ágústsdóttir et al., 2016, with earliest events plotted on top); volcanoes and calderas outlined; ice cauldrons - formed by subglacial melting - marked by purple diamonds (Dyngjujökull cauldron locations from Reynolds et al., 2017; Bárðarbunga cauldron locations from Gudmundsson et al., 2016); subaerial eruption fissures marked by orange diamonds; new Holuhraun lava in dark grey. Study area marked by red box. Segments S1-4 discussed in text. Inset: Location map with rift zones shaded.

On 16 August 2014, a seismic swarm marked the initiation of a radial dike intrusion from Bárðarbunga caldera. Over the next 13 days, volcano-tectonic (VT) earthquakes at $\sim 6 \mathrm{~km}$ depth below sea level (b.s.l.) tracked melt as it intruded $\sim 50 \mathrm{~km}$ laterally, from the central volcano north-eastwards to the icefree Holuhraun lava field (Ágústsdóttir et al., 2016; Caudron et al., 2018). The 
dike was segmented and propagated with varying speeds, following a pathway of minimum potential energy largely governed by topographic loading (Sigmundsson et al., 2015; Heimisson et al., 2015). On 29 August a minor, 4-hour fissure eruption reoccupied the 18 th century Holuhraun craters at the distal (northern) end of the dike. On 31 August a major, effusive fissure eruption began, initially as a $1.6 \mathrm{~km}$ long curtain of fire, then localizing down into individual vents, with the main vent known as Baugur. The eruption continued until the end of February 2015, during which time Bárðarbunga caldera gradually collapsed by $\sim 65$ $\mathrm{m}$, indicating deflation of an underlying magma reservoir (Gudmundsson et al., 2016).

In addition to the main fissure at Holuhraun, minor eruptions occurred at several other points along the dike pathway, both subaerially and subglacially. Three ice cauldrons - depressions in the overlying ice formed by subglacial melting - developed on the glacier during the dike propagation (Icelandic Meteorological Office, 2014; Reynolds et al., 2017), each marking small, subglacial eruptions. Additionally, a separate, short-lived subaerial fissure erupted south of the main fissure, several days after the main eruption onset. In this sense, the dike somewhat resembled a leaky pipe, particularly in the distal $20 \mathrm{~km}$.

The dike emplacement was associated with surface deformation, with fracturing, graben formation and subsidence above the path of the dike during its propagation (Ruch et al., 2016; Rossi et al., 2016; Hjartardóttir et al., 2016). Surface widening of $\sim 4.5 \mathrm{~m}$ was observed directly above the dike (Ruch et al., 2016 ), with up to $\sim 1 \mathrm{~m}$ spreading between GPS sites $\sim 10 \mathrm{~km}$ to the east and west of the dike (Sigmundsson et al., 2015). Geodetic modeling (Sigmundsson et al., 2015; Spaans and Hooper, 2018) suggests the dike was near-vertical and extended almost to the surface along its length, with variable opening on the order of several meters.

Intense seismicity accompanied the dike intrusion, with over 31,000 VT earthquakes detected during the dike propagation phase alone (Ágústsdóttir et al., 2016). Subglacial tremor and long-period earthquakes - indicative of fluid-involvement - were also observed (Woods et al., 2018), and vent tremor occurred throughout the main eruption period (Eibl et al., 2017). This study concentrates on the VT seismicity in the distal $(\sim 15 \mathrm{~km})$ section of the dike (Figure 1), where seismicity continued to occur during both the eruption and post-eruption phases. In this region the seismic network is very dense, allowing high-resolution analyses to be made. Interpretation is further aided by surface deformation observations, particularly in the ice-free northern region where surface fracturing and InSAR give high spatial resolution.

\section{Data}

The microseismicity accompanying the 2014-15 Bárðarbunga rifting event was recorded in unprecedented detail by the University of Cambridge seismic 
network, which in August 2014 comprised 72 three-component broadband seismometers (see Supplementary Figure S1). To complement the network, stations from the national seismic network of the Icelandic Meteorological Office were used, as well as one British Geological Survey station and one University College Dublin station. The network provides good azimuthal coverage, with excellent sampling north of the ice cap. Coverage is less good to the south of the dike due to difficult field conditions on the ice cap. The data used cover the period from August 2014 to August 2015, encompassing the dike intrusion, the 6-month eruption and 6 months post-eruption. All data were recorded at $100 \mathrm{~Hz}$ sample rate with a GPS time stamp. The work presented here builds on the automatic earthquake catalogs from Ágústsdóttir et al. (2016) and Greenfield et al. (2018).

\section{Methods}

Earthquakes automatically detected and located in the distal $\sim 15 \mathrm{~km} \mathrm{sec-}$ tion of the dike (Figure 1) during the propagation, co-eruption and post-eruption phases (using Coalescence Microseismic Mapping, Drew et al., 2013) were relocated using cross-correlated, sub-sample relative travel times to reveal exceptional detail in the earthquake hypocentral locations. Relocations of the $>$ 30,000 earthquakes were obtained via a three-step process consisting of 1) refinement of relative travel times by cross-correlation using the GISMO toolkit (Reyes and West, 2011), 2) relative relocation with hypoDD (Waldhauser and Ellsworth, 2000), and 3) realignment with manually-refined locations and surface features for absolute locations.

To make the task computationally feasible, the earthquakes were sorted by latitude and divided into subsets of 2400 earthquakes, then cross-correlated and relocated separately. To align the subsets with one another afterwards, the relative relocation procedure was also carried out for subsets of earthquakes $50 \%$ overlapping the first subsets. This enabled sequential alignment of each subset with respect to the next (by aligning with the $50 \%$ overlapping events), to obtain a complete, relatively-relocated catalog. Absolute locations were then determined by realignment of the relatively-relocated catalog with manuallyrefined absolute locations and surface features.

\subsection{Refinement of arrival times by cross-correlation}

Events were cross-correlated in subsets of 2400 earthquakes. Traces were bandpass filtered between 2 and $20 \mathrm{~Hz}$, and cross-correlated over a short window $(-0.5 \mathrm{~s}$ to $2 \mathrm{~s})$ around the automatic pick time for both $\mathrm{P}$ and $\mathrm{S}$ phase arrivals, on vertical and horizontal components respectively. Event traces were then realigned on the maximum cross-correlation (cc) coefficient to achieve subsample, relative travel times. A minimum cc coefficient of 0.6 was imposed, and traces requiring a shift (lag time) of $>0.5 \mathrm{~s}$ were discarded. Noisy stations were found to be vulnerable to producing spurious results and so were not used $(\sim$ 30 out of 100). 


\subsection{Relative relocation with hypoDD}

Relative relocation of the hypocenters using the differential travel times (again in subsets) was carried out with hypoDD (Waldhauser and Ellsworth, 2000), using a simple 1D velocity model shown in Supplementary Figure S2. To remain within computational limits, the minimum cc coefficient was (variably) increased at this stage such that approximately 4000 refined differential travel times were used for each event, with an average cc coefficient of 0.77. Observations were then weighted by the square of the cc coefficient. Since relocations are relative, events not located in the main hypoDD cluster (i.e. with locations relative to only a handful of other events) were discarded. The discarded events - 625 out of $>30,000$ total detected events, or $\sim 2 \%$ - are probably earthquakes with less typically volcano-tectonic natures, such as the clusters of long-period earthquakes presented in Woods et al. (2018), and therefore are not the focus of this study.

Relative location uncertainty, or precision, of the relocated events is difficult to quantify. We observe that overlapping subsets of events, separately crosscorrelated and relatively relocated, delineate the same 100-200 m scale features, so it can be assumed that uncertainties are of the order of $<100 \mathrm{~m}$. Got et al. (1994) show that relative location uncertainty is proportional to a number of factors: error in delay, azimuth and take-off angle, and inversely proportional to the square root of the number of events. In their study of 252 events, precision was found to be $50 \mathrm{~m}$ laterally and $75 \mathrm{~m}$ vertically, so with the greater number of seismic stations and events available in our network we estimate that precision will be of the same order or better.

\subsection{Obtaining absolute locations}

After cross-correlation and relative relocation in subsets of 2400 earthquakes (owing to computational limitation), it was necessary to realign the subsets with one another. Subsets were sequentially aligned with respect to the next subset, each time taking the average location of the 1200 overlapping events, to obtain a complete catalog of $>30,000$ relative locations. Supplementary Figure S3 shows this procedure.

Absolute locations were then determined by manually-refining locations (refining phase arrivals and locating with NonLinLoc, Lomax et al., 2000) for a sample of 80 events, well-distributed along the dike section, and applying the average latitude, longitude and depth shift between the relocations and the single-event locations to all events in the catalog. The absolute location uncertainties are typically $\pm 0.3 \mathrm{~km}$ in latitude and longitude, and $\pm 0.6 \mathrm{~km}$ in depth, shown in Supplementary Figure S4. Uncertainty arising from the velocity model used was also explored, finding that relatively small model changes can significantly impact depth (by up to $\sim 1 \mathrm{~km}$, see Supplementary Figures S5 and S6). 
The resultant hypocentral catalog - i.e. aligned with the sample of manually refined events - exhibited a small $(\sim 500 \mathrm{~m})$, clearly systematic WNW offset from the graben, fractures and fissures, so the static latitude and longitude shift was modified to laterally align with these surface features. This shift also results in aligning the seismicity with the center of the graben, in agreement with deformation data and modeling. The boundary faults of the graben are approximately symmetric and dip at $\sim 75^{\circ}$ (Hjartardóttir et al., 2016), and are assumed to intersect at the top of the dike. Deformation data requires the dike to be approximately vertical and align with the seismicity (Sigmundsson et al., 2015), and more detailed deformation modeling - including the graben, with $60^{\circ}$ dipping bounding faults - is fit by a dike in the central axis of the graben (Ruch et al., 2016). This $\sim 500 \mathrm{~m}$ shift is of the order of the manual location uncertainty (slightly larger than the $68 \%$ confidence ellipsoid but within the posterior probability density function scatter, see Supplementary Figure S4). However, the systematic nature of the offset implies that there is a systematic error in the location. This likely arises from the use of a $1 \mathrm{D}$ velocity model - i.e. with no lateral variation - in undoubtedly heterogeneous (intruded, fractured) Icelandic crust, which is known to be anisotropic (Menke et al., 1994). A rough estimate of the lateral velocity variation required for a $\sim 500 \mathrm{~m}$ change in station distance (details given in Supplementary Section S3.2) suggests that velocity variations on the order of $\sim 5 \%$ could produce the observed systematic offset in hypocenters. This seems reasonable, given that seismic tomography beneath the northern part of the network, centered around Askja volcano, reveals local velocity variations of up to $\pm 10 \%$ (Greenfield et al., 2016).

\subsection{Focal Mechanisms}

Moment tensor solutions were obtained using MTfit (Pugh and White, 2018), a Bayesian source inversion method. Phase arrival polarities were manually determined at each station across the network and the pick confidence translated into a polarity probability density function. A double-couple (DC) solution could be imposed, or the fitting could be left unconstrained (non-DC).

Earthquake failure mechanisms were also analyzed using a categorization method based on the consistency of the DC solutions (dominantly strike-slip failure with tightly clustered nodal planes), enabling quick categorization between left- and right- lateral shear failure. See Ágústsdóttir et al. (2016) for details.

\section{Results}

Dike-induced earthquakes automatically located during the dike propagation, co-eruption and post-eruption phases were relocated by cross-correlation (to obtain sub-sample relative phase arrival times) and relative relocation. This process markedly improves the spatial resolution - see Figure 2 inset - achieving exceptional $(\sim 100 \mathrm{~m}$ scale $)$ detail. 


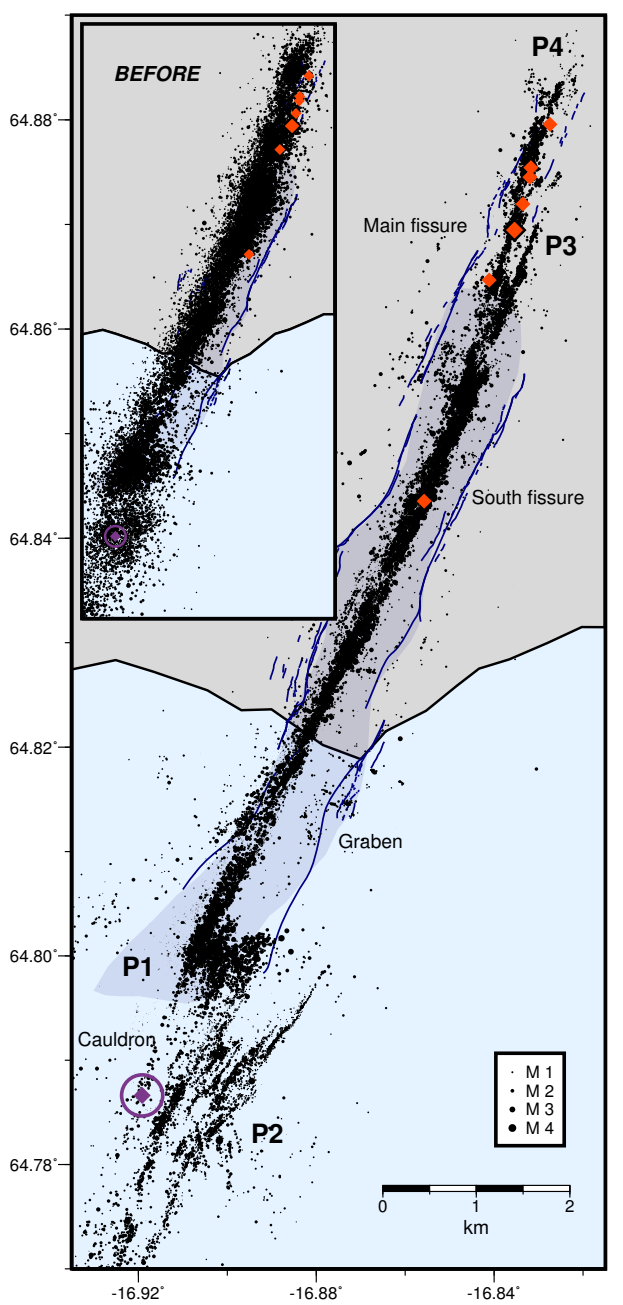

Figure 2: Cross-correlated, relatively-relocated dike-induced earthquakes - in black, scaled by magnitude - between August 2014 and August 2015 (spanning propagation, co-eruption and post-eruption phases). Vatnajökull ice cap in light blue; ice cauldron indicated by dark purple diamond (location and diameter from Reynolds et al., 2017), eruption fissures shown as orange diamonds; graben shaded (digitized from Rossi et al., 2016) and surface fractures in navy (Hjartardóttir et al., 2016). Inset: Earthquake locations before cross-correlation and relative-relocation. See Supplementary Movie 1 for earthquake timings. Points of interest (P1-4) discussed in text.

\subsection{A complex, segmented, lateral intrusion}

On a large scale, the dike intruded as 4 main segments (S1-4 in Figure 1). The relocations presented here all lie well within the northernmost 'large-scale' segment (S4). Prior to relocation, the diffuse spatial distribution of hypocenters did not indicate smaller-scale segmentation, and shed no light on the reason for areas of concentrated seismicity. With the resolution now achieved, it becomes 
evident that the intrusion was far more complex.

Relocation of microseismicity along the distal section of the dike (Figure 2) collapses the hypocenters onto lineations, reflecting small-scale segmentation instead of a diffuse epicentral zone. At the southern end of the graben a significant side-step, or 'junction', between segments is observed (P1, Figure 2), with the dike stalling here for $\sim 12$ hours before propagating along the western segment. Alongside the ice cauldron, a dense array of linear features is observed (P2), highlighting either dike fingers or fractures accommodating the opening, discussed later (Section 4.3). Segmentation is also observed at the main eruption site, with two neighboring pathways delineated (P3). From the origin times of these earthquakes, we find that the dike propagated first along the eastern pathway adjacent to the eventual eruption site, before halting and then breaking the western pathway beneath the eruption craters (see Supplementary Movie 1).

\subsection{Dynamics of dike propagation and induced seismicity}

The advancing dike tip is marked by the leading edge of the seismicity (Figure 3), with the gradient showing the propagation velocity. A distinct, step-like pattern highlights the jerky dynamics of the dike emplacement. Propagation phases are identified by concentrated migrating seismicity induced near the dike tip, with trailing aseismic zones (vertical white bands in Figure 3). When the dike tip is stationary, i.e stalled phases, seismicity is induced along the length of the dike section behind the tip $(>10 \mathrm{~km})$ as pressure builds and the dike inflates. The largest magnitude earthquakes $(\sim \mathrm{M} 2-3)$ were induced at the propagating dike tip, along the section of the dike where the graben formed and most opening occurred. After the tip had passed, seismicity was generally of smaller magnitude ( $\sim$ M 0-2), although larger magnitude events continued to occur at points where the dike stalled during propagation (e.g. at the step between segments at the southern end of the graben, P1 in Figure 2).

We find that the dike reached the eventual eruption site two days prior to first erupting (with the pattern of surface fracturing indicating magma at $<300$ $\mathrm{m}$ depth, Hjartardóttir et al., 2016), and in fact continued intruding beyond the eruption site before breaking the surface $\sim 1 \mathrm{~km}$ back from the tip (P4, Figures 2 and 3). Onset of the first (minor, 4-hour) eruption was accompanied by an immediate drop in the rate of seismicity, while magma flowed out of the open system. Once closed again, seismicity readvanced along the length of the dike segment, indicating reinflation of the dike with reinflux of melt and increasing pressure. With onset of the main (6-month) eruption, the seismicity rate again dropped, but persisted at a lower rate along the entire segment. Fluctuations are visible in early September (on an hours to day time-scale, see P5, Figure 3), suggesting that although the dike had opened and magma was flowing, some dynamic change (e.g. dike inflation/deflation) was occurring and influencing the induced seismicity. Throughout the eruption and post-eruption phases diffuse seismicity was observed along the length of the dike section (Figure 3C). A general decay in seismicity rate, earthquake magnitude and moment release 

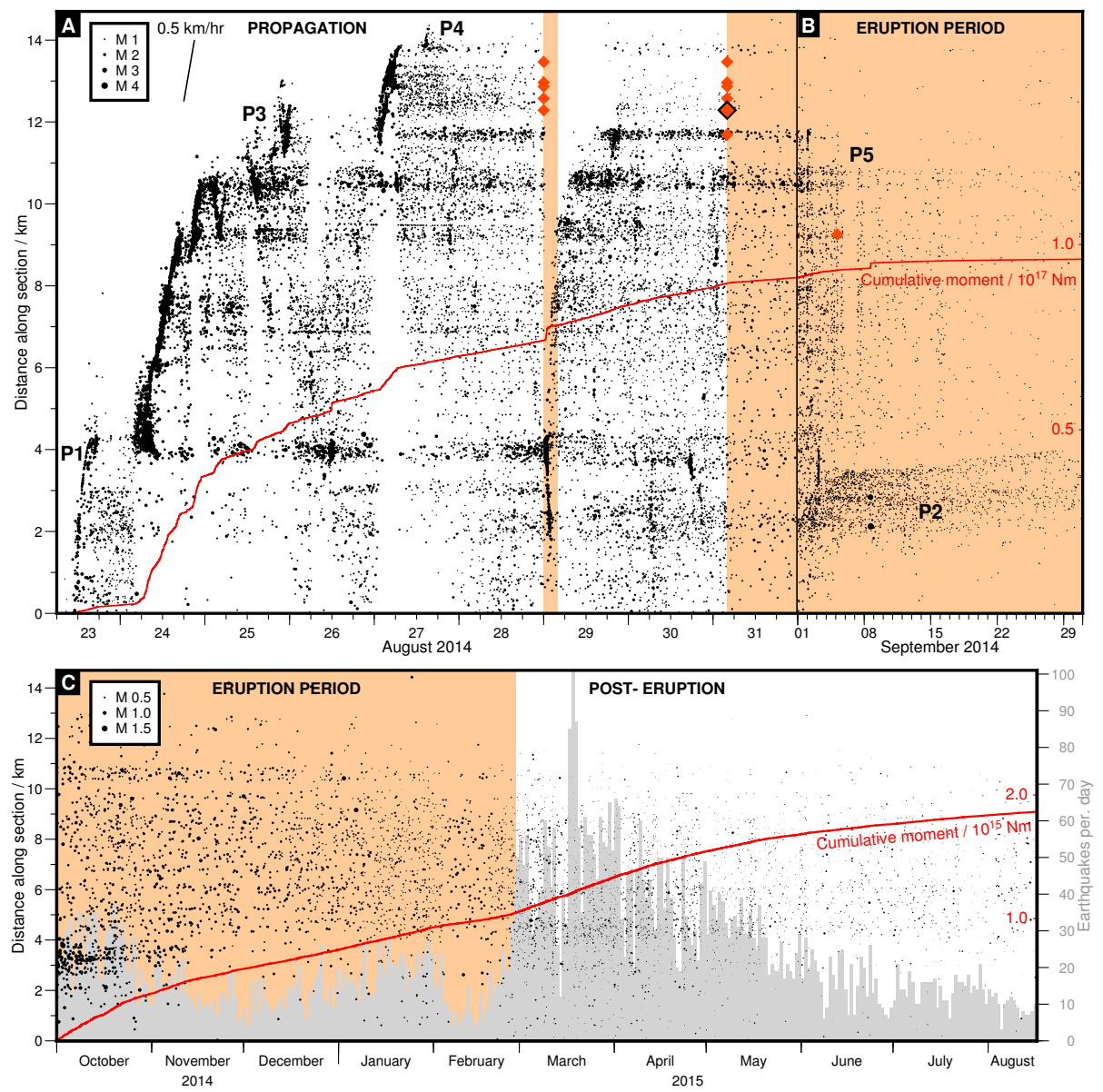

Figure 3: Relocated earthquakes along dike section through time for A) dike intrusion (Aug 2014), B) first month of eruption (Sept 2014) and C) eruption and post-eruption periods. Earthquakes as shown in Figure 2, projected along SW-NE dike-parallel section, scaled by magnitude. Eruption fissures shown as orange diamonds; eruption periods marked by orange bands. Cumulative moment for earthquakes in A/B and C shown by red lines. Note changes in time, magnitude and moment release scales. In $\mathrm{C}$, earthquake histogram given in grey (daily bins). Points of interest (P1-5) discussed in text.

was observed through both phases, although the end of the eruption was initially followed by an increase in the number of earthquakes. This is inferred as arising from an increase in conduit magma pressure resulting from blockage of the vent, although we note that our earthquake detection threshold is markedly lower without vent activity and so the observed increase could instead be a result of this.

In summary, the dynamics of the seismicity induced during emplacement of the dike can be directly linked to propagation of the tip and opening of the dike. 
Following this - after dike opening - the spatio-temporal characteristics of the seismicity indicate a relationship with conduit magma pressure, discussed later. We strongly encourage readers to view Supplementary Movie 1 which shows the dike-induced earthquakes in 3D through time and highlights these (and other) interesting features.

\subsection{Location and characteristics of dike-induced seismicity Depth extent}

In general, the relocated dike-induced seismicity appears to reflect the lateral extent of the dike intrusion, however the same cannot be said for the depth extent. The depths of the earthquakes show that the seismicity occurred within a narrow depth range, at 6-7 km depth below sea level (b.s.l.) (Figure 4). The absolute location uncertainties in depth are $\pm 0.6 \mathrm{~km}$ (shown in Supplementary Figure S4), but it must also be acknowledged that inaccuracy in the velocity model may introduce depth uncertainty of up to $\pm 1 \mathrm{~km}$ (explored in Supplementary Section S3.2, Figures S5 and S6). Even with this in mind, we observe that the majority of the dike opening inferred from geodetic measurements occurred at shallower depths (most opening at $<3 \mathrm{~km}$ b.s.l, Sigmundsson et al., 2015; Ruch et al., 2016; Spaans and Hooper, 2018) without producing any seismicity. This serves as a reminder that the induced seismicity does not represent the extent of the dike; indeed, the cumulative moment of the seismicity was two orders of magnitude smaller than the modeled geodetic moment for opening the dike (Green et al., 2015; Ágústsdóttir et al., 2016). Even where the magma propagated to the surface and erupted, there was almost no seismicity recorded in the upper $5 \mathrm{~km}$ of crust (Figure $4 \mathrm{~B}$ ).

\section{Failure mechanisms}

The exceptional spatial resolution, combined with the fault motion categorization from Ágústsdóttir et al. (2016) and $~ 300$ manually-constructed focal mechanisms, provides a detailed picture of the characteristics of the dike-induced seismicity (Figures 5 and 6). Left-lateral strike-slip failure was dominant in the northern section of the dike studied here, accommodating both the dike opening and the regional spreading deficit in the brittle crust since the last rifting episode. We find that the seismicity is concentrated along lineations, with arcshaped features visible in depth view along the dike (Figure 5B). Focal mechanisms show that the strikes of the fault planes are highly consistent, rotated from and independent of the dike strike. We infer therefore that the fault plane strikes are governed by the pervasive underlying fabric of the host rock, and induced to fail by the stresses imposed by the dike emplacement above. The larger scale linear features - strikingly picked out by earthquake slip direction (green vs red in Figure 5) - likely arise from crustal heterogeneities and stress concentrations. The tightly-clustered strikes of the manually-constructed focal mechanisms show that most of the fractures are rotated clockwise from the dike strike, and thus left-lateral slip was favored to accommodate the dike opening. Right-lateral slip occurred on fractures rotated anti-clockwise from the dike 

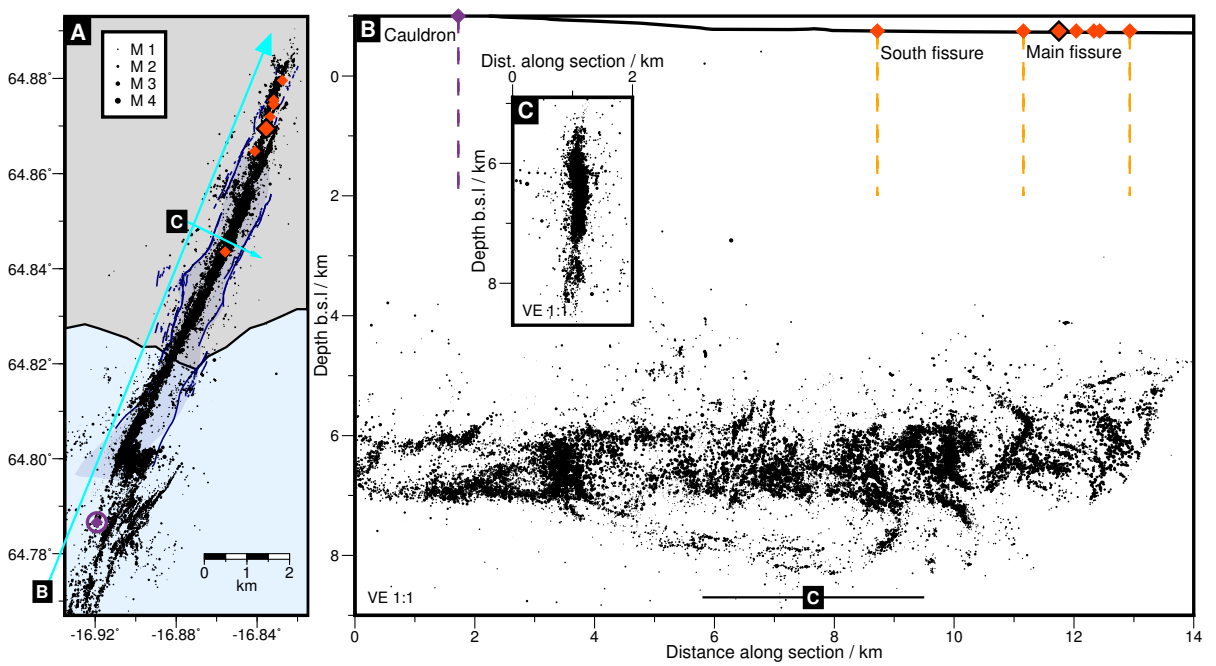

Figure 4: Depths of relocated earthquakes. A) Map view with cross-section locations; B) dike-parallel depth cross-section with topography; C) dike-perpendicular depth cross-section (earthquakes shown marked in B). Both cross-sections VE 1:1. Earthquakes scaled by magnitude. Ice cauldron indicated by dark purple diamond; eruption fissures marked by orange diamonds. See Supplementary Movie 1 for earthquake timings.

strike and therefore required the opposite slip direction to accommodate dike opening.

This behavior (strike-slip faulting along tightly-clustered fault plane strikes) is observed along the length of the dike section, however the region south of the graben (Figure 6B) is somewhat more complex; reverse faulting and long-period earthquakes are also observed (presented in Woods et al. 2018). We find that in this region hypocenters are not concentrated along a clear 'dike pathway' (initial intrusion pathway marked by red dashed line in Figure 6): rather there is a dense array of linear features adjacent to the step between segments (P2, Figure 6). Detailed analysis of manually-constructed focal mechanisms shows that here, again, fault plane strikes appear to be independent of the orientation of lineations delineated by the hypocenters. Timing of the earthquakes reveals that the features developed mostly during the eruption phase (Figure 3 and Supplementary Movie 1). It is therefore unlikely that this seismicity reflects dike fingers (i.e. seismicity induced directly beneath a melt pathway), but was instead induced nearby by the large amount of opening; geodetic models show opening was largest in this region (Sigmundsson et al., 2015), and so positive stress lobes would therefore extend further away from the dike. However, the presence of multiple melt pathways cannot be excluded; long-period earthquakes - indicative of fluid processes - and known subglacial eruptions occurred to the western side of the region (subglacial eruption location indicated by ice cauldron - purple diamond in Figure 6, location from Reynolds et al., 2017). 

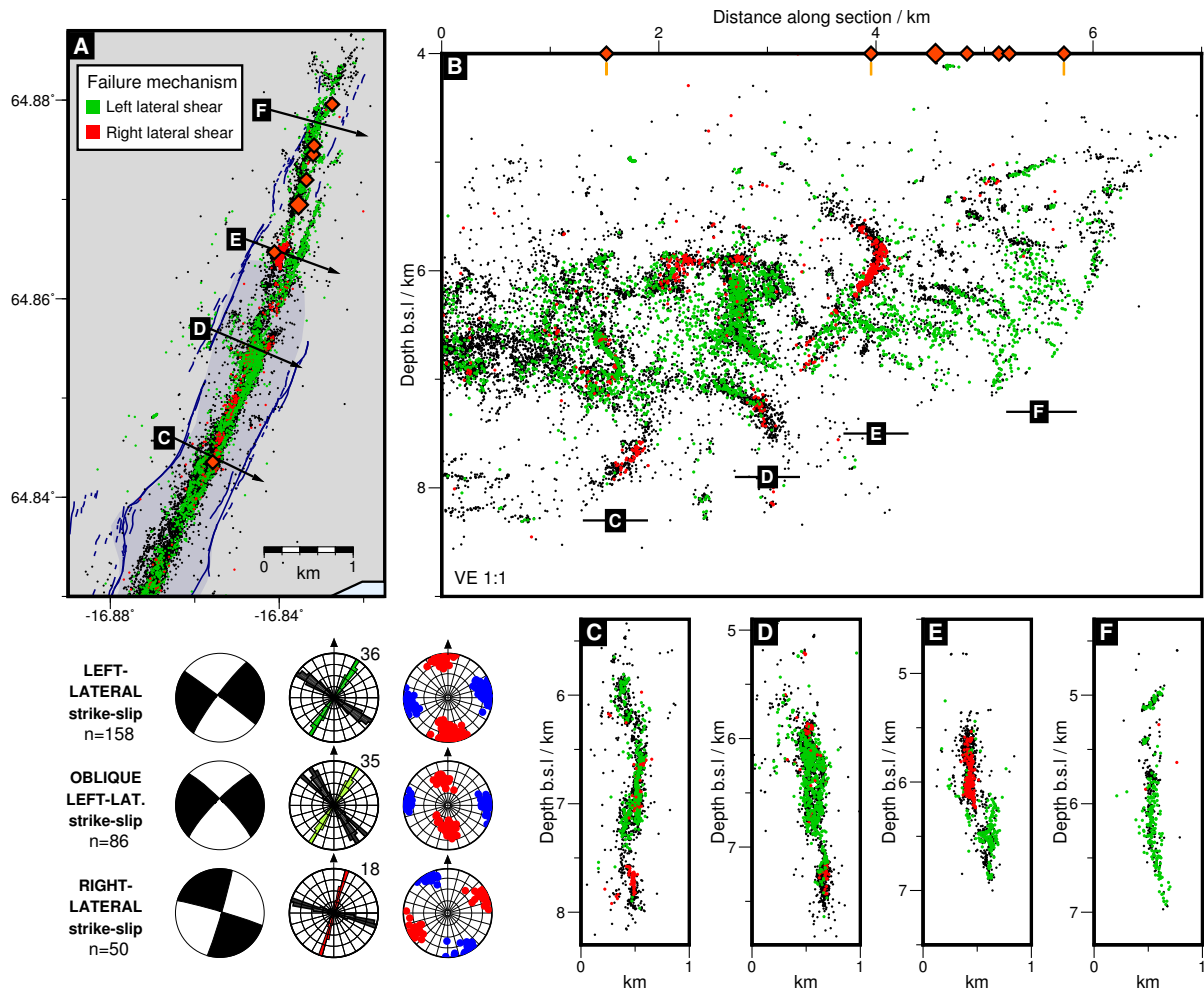

Figure 5: Failure mechanisms of dike-induced earthquakes. A) Map view (zoom) with dike-perpendicular cross-section locations annotated; B) dike-parallel (SW-NE) depth crosssection; C) to F) dike-perpendicular depth cross-sections (earthquakes shown marked in B). All cross-sections VE 1:1. Earthquakes colored by failure mechanism (categorization as leftlateral or right-lateral shear failure, described in Ágústsdóttir et al. 2016); N.B. earthquakes are not scaled by magnitude. Locations of eruption fissures marked by orange diamonds; graben shaded and surface fractures in navy. Manually-obtained focal mechanisms given in bottom-left: average double-couple fault plane solutions; rose diagrams (fault planes in color with average, auxiliary planes in grey); P (red) and T (blue) axes.

\section{Discussion}

We have cross-correlated and relatively-relocated dike-induced seismicity during the 2014-15 Bárðarbunga rifting event, and analysed in detail the location, timing, failure mechanisms and magnitudes of the earthquakes (see Supplementary Movie 1 and Figures 2 to 6). The spatial resolution achieved by relative relocations reveals the dike propagation dynamics and allows us to address the nature and extent of dike-induced seismicity during this exceptionally well-recorded case study.

\subsection{Propagation dynamics}

The 2014 Bárðarbunga dike propagated $\sim 50 \mathrm{~km}$ laterally along the NE fissure swarm, relieving the $\sim 4 \mathrm{~m}$ extension deficit in the brittle crust accumu- 


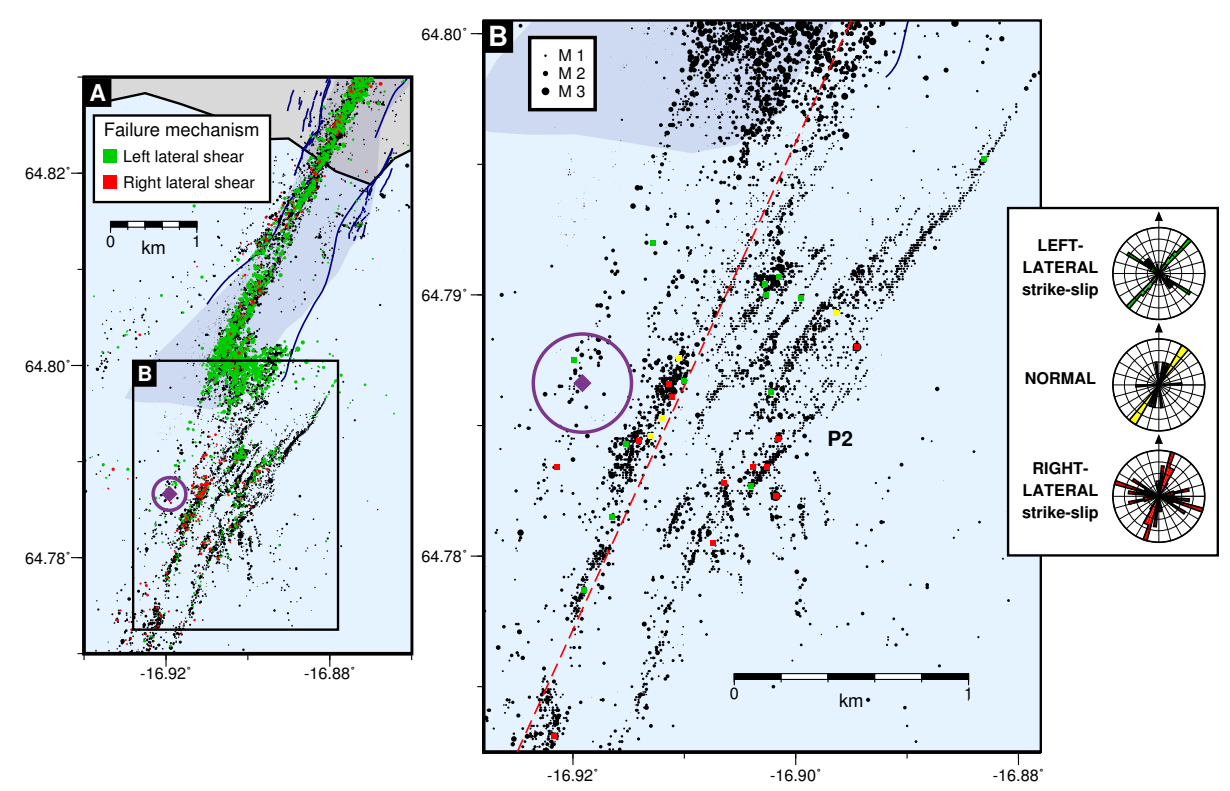

Figure 6: Failure mechanisms of dike-induced earthquakes at southern end of dike section (junction between segments). A) Earthquakes colored by categorization as left-lateral (LL) or right-lateral (RL) shear failure, described in Ágústsdóttir et al. (2016). Graben in dark blue; surface fractures in navy; ice cauldron (subglacial eruption location) marked by purple diamond. B) Zoom in of region adjacent to step between segments, with dashed red line indicating initial intrusion pathway. Earthquakes scaled by magnitude, with well-constrained manually-picked events marked by colored diamonds (colored by failure mechanism) and accompanying rose diagrams given on right. Double-couple fault plane solutions (beachballs) shown in Supplementary Figure S8. Point of interest (P2) discussed in text.

lated since last rifting over 200 years ago (Ruch et al., 2016). It has been shown that the propagation direction of the dike was in part governed by deviatoric stresses from plate spreading (18.5 mm per year, DeMets et al., 2010), but primarily controlled by topographic loading, resulting in emplacement oblique to the least compressive stress and thus causing left-lateral shear motion along the dike (Heimisson et al., 2015; Urbani et al., 2017) and a prevalence of left-lateral shear failure. The dike stalled at Holuhraun, a topographic low, re-activating a pre-existing graben and erupting through pre-existing craters (formed during the 18th century rifting event, Hartley and Thordarson, 2013). This indicates that pre-existing weaknesses also played a role in controlling the propagation pathway (Ruch et al., 2016).

Four main segments were emplaced (S1-4 in Figure 1), but, examined more closely, our relocations tell a story of a much more finely segmented, jerky intrusion (Figures 2 and 3). The dike frequently stalled, having reached an energy barrier requiring a build-up in pressure to overcome it (perhaps due to crustal inhomogeneity, (Rivalta et al., 2013), or perhaps solidification of the dike, 
(Taisne and Tait, 2011)). In some cases the dike side-stepped and continued, e.g. at the junction between segments south of the graben (P1, Figure 2), whereas sometimes it tried a different neighboring pathway, e.g. at the eruption site (P3, Figure 2), always exploiting weaknesses to find the path of least resistance. Ultimately, although it propagated $\sim 1 \mathrm{~km}$ beyond the eventual eruption site (P4, Figures 2 and 3), the route to the surface was more energetically favorable than advancing further (with increasing topographic load).

\subsection{Nature and extent of dike-induced seismicity}

The microseismicity induced by the dike intrusion reflected the lateral extent of the dike, with seismicity confined to $\sim 5-7 \mathrm{~km}$ b.s.l., despite maximum extension occurring at $<3 \mathrm{~km}$ b.s.l. (Sigmundsson et al., 2015). The seismicity accounted for two orders of magnitude less moment release than the deformation (Green et al., 2015; Ágústsdóttir et al., 2016), as previously observed during the 1975-1984 Krafla rifting episode in Iceland (Hollingsworth et al., 2013) and for many of the dikes during the 2005-2010 Dabbahu rifting event in Afar (e.g. Keir et al., 2009; Wright et al., 2012). Dike-induced earthquakes are expected to occur on suitably-aligned pre-existing weaknesses that are close to the dike and already near to failure (Rubin and Gillard, 1998; Rubin et al., 1998). The limited depth extent therefore implies that dike-imposed stresses - combined with the background tectonic stress - were only sufficiently large to induce failure in the host rock at the base of the dike, where ambient differential stresses from divergent plate spreading would have been largest (near the brittle-ductile boundary, mapped at $7 \mathrm{~km}$ depth in the region, (Key et al., 2011)). Simple Coulomb modeling - shown in Figure 7 - indeed predicts negative stress changes, i.e. suppression of failure, where the dike opening is greatest, and positive stress changes, or promotion of failure, as the opening tends to zero and beneath the dike. Where the dike did not extend to the surface, positive stress changes would also be observed above the dike. However, at these shallow depths ambient differential stresses may not have been great enough to produce earthquakes, or failure may have been predominantly mode I as pre-existing cracks were widened.

We find that the seismicity was almost exclusively produced by strike-slip failure, on planes with tightly-clustered strikes sub-parallel to the dike. Previously, without the spatial definition achieved here, this was interpreted as conjugate tip fracturing of intact rock. However, the clustering of like failure mechanisms (Figure 5) instead indicates that seismicity was induced on pre-existing fractures (as is often observed, e.g. during the 2000 dike at Miyakejima, Japan, Toda et al., 2002; Passarelli et al., 2015). It is worth noting that no background seismicity was observed anywhere along the dike pathway prior to intrusion. Elsewhere, dike-induced seismicity has been found to occur only in regions of persistent background seismicity (e.g. during the 1983 dike intrusion at Kilauea volcano, Hawaii, Rubin et al., 1998). Seismic productivity is, however, related to the pre-existing stress state in the rift zone (Rubin and Gillard, 


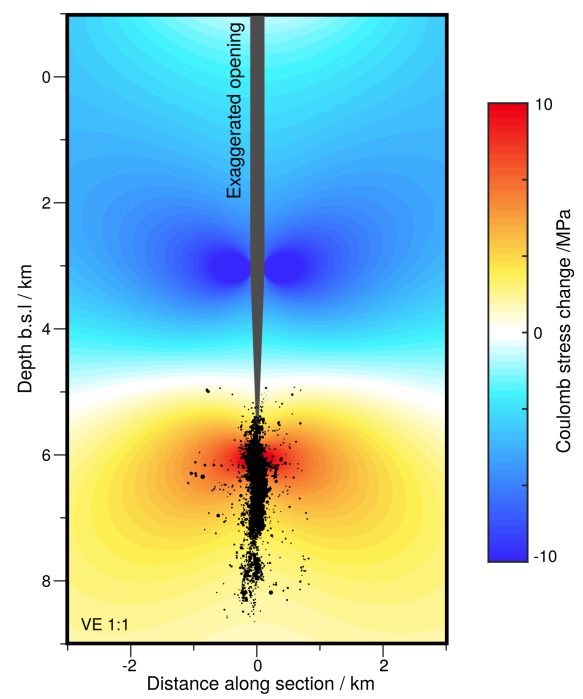

Figure 7: Coulomb stress change induced on receiver faults with strike/dip/rake 035/090/0 (left-lateral strike-slip) by dike opening (strike 025) of $4 \mathrm{~m}$ of opening from the surface to 3 $\mathrm{km}$ b.s.l., linearly tapering to zero at $6 \mathrm{~km}$ b.s.l.. Dike opening approximated from opening model by Sigmundsson et al. (2015) (constrained by GPS and InSAR data).

1998; Pedersen et al., 2007), among other factors. In this instance regional extension and a reasonably long inter-rifting period introduced sufficiently high ambient differential stresses for dike-imposed stresses to produce large amounts of seismicity along the entire dike pathway. Larger magnitude earthquakes are expected for larger imposed stresses, such as when dikes intrude after a long quiescence (e.g. estimated $\mathrm{M}>5$ earthquakes during 1874 Askja rifting event, following 400 years of quiescence, Brandsdóttir, 1992). We find that the largest magnitude events ( M 3-4) and the majority of moment release occurred along (and at the step into) the distal dike segment, coinciding with the region of most dike opening modeled by Sigmundsson et al. (2015). Further south, under the glacier, it is thought that rifting had already been somewhat accommodated by earlier undetected intrusions (Spaans and Hooper, 2018), therefore less seismicity was induced by the dike; seismicity was only observed in the earlier largescale segments (S1-3, Figure 1) during their initial emplacement/opening phase.

To address the precise location of the earthquakes in relation to the magma - i.e. whether they are beneath or at the same depth as the dike - we consider the spatio-temporal characteristics exhibited by the induced seismicity. During propagation phases, aseismic zones trailed the concentrated migrating seismicity. This behavior is characteristic of seismicity induced near to the advancing dike tip, at the same depth as the dike, shutting off when the tip passes and the region falls into a stress shadow (Segall et al., 2013). However, between propagation phases, seismicity was observed at the same depths along the length of the 
dike segment; similarly, throughout the eruption and post-eruption periods (to date), seismicity has remained persistent at the same depths. For a simplified, uniform opening model (with depth), this behavior indicates that the seismicity occurred beneath the dike, along the length of the inflating (widening) region, where it is expected to continue at a decaying rate after the dike tip has passed (Segall et al., 2013; Toda et al., 2002). In a more realistic scenario, with dike opening tapering to zero at depth (Figure 7), seismicity would also be expected to persist adjacent to the base of the dike, after the tip has passed, in the depth range where opening is decreasing. With this in mind, the lack of seismicity behind the tip during propagation phases may not have been a stress shadowing effect, and may instead have been a result of a relative decrease in pressure and deflation (narrowing) from rapid lengthening of the dike (below geodetic resolution), combined with high magnitude events having reduced the ambient differential stress.

In early September - after dike opening and onset of the main eruption marked fluctuations in the seismicity rate along the dike segment were observed (see Figure 3), suggesting that dynamic changes were occurring and influencing the induced seismicity. It is attractive to link these changes in seismicity rate to pressure fluctuations in the conduit. By comparison, the eruption onset was marked in both instances (initial, 4-hour; and main, 6-month) by a drop in seismicity rate, as a pathway to the surface had opened and magma was flowing freely, presumably accompanied by a decrease in pressure. Gudmundsson et al. (2016) report short-term coupling between caldera subsidence events and the distal dike seismicity rate (i.e. 'pressure pulses' connecting caldera subsidence and distal dike pressure), although the evidence is not conclusive. However, if indeed influenced by fluctuations in magma pressure, this suggests that the seismicity was relatively close to the conduit flow - i.e the dike had opened shallower but for the most part melt had frozen in the upper section, and flow was concentrated at depth (as also indicated by melt inclusion analysis, Hartley et al., 2018). A simple cooling estimate (details given in Supplementary Material Section S5) predicts complete cooling to take between a day and a month for a shallow crack 1-4 m wide, with enough cooling to stop flow therefore occurring in an even shorter time frame. With no appreciable shallow flow, a rectangular conduit of just $\sim 7 \mathrm{~m} \mathrm{x} 100 \mathrm{~m}$, or a tube of $\sim 16 \mathrm{~m}$ diameter (or similar), at 5-6 $\mathrm{km}$ depth b.s.l. could satisfy the observed eruption rate (Sigmundsson et al., 2015; Ágústsdóttir et al., 2016). Schematic given in Figure 8B.

This discussion of the induced seismicity is by no means exhaustive. The relocated hypocenters reveal a wealth of intriguing spatio-temporal characteristics, best visualized in Supplementary Movie 1. For example, backward migrations of seismicity (observed elsewhere, e.g. Brandsdóttir and Einarsson, 1979; Keir et al., 2009; Belachew et al., 2011, and previously identified during this event by Ágústsdóttir et al. 2016 and Caudron et al. 2018), are found to deepen with backward migration, perhaps indicating inflation back from the dike tip. This pattern is most prominent on $25 \mathrm{Aug}$ (01:00 - 04:00, and again 12:00 - 15:00) 

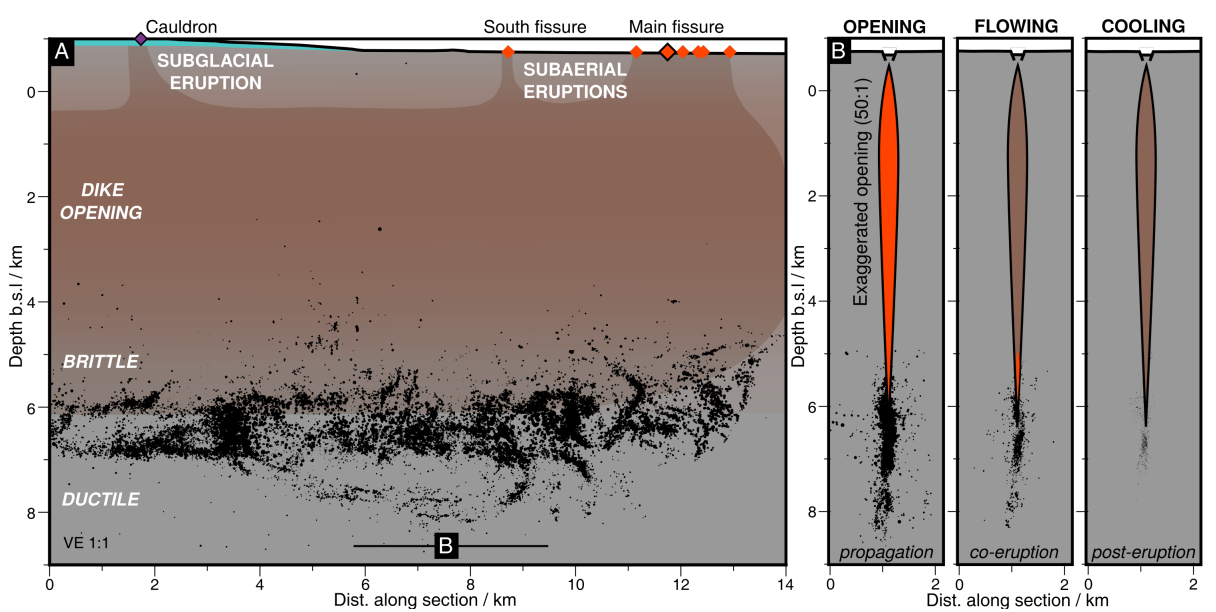

Figure 8: A) Dike-parallel cross-section with schematic dike opening shaded and B) dikeperpendicular cross-section with interpretative cartoon for propagation, eruption and posteruption phases. Relocated dike-induced earthquakes, scaled by magnitude, as shown in Figure 4. Ice cauldron indicated by dark purple diamond; eruption fissures shown as orange diamonds.

- see Figure 3 and Supplementary Movie 1 (for depths). A distinct backward migration of seismicity was also observed on $29 \mathrm{Aug}$, from the southern end of the graben segment to beneath an ice cauldron (minor subglacial eruption location). The relocation resolution shows that this seismicity migrated through a previously aseismic area (see Movie, 29 Aug 00:00), suggesting southward extension of the dike segment. This continued development of segmentation, and further fracturing in this region of greatest opening after the main eruption onset (P2, Figures 3 and 6), really emphasises the complexity of the intrusion and induced seismicity.

\section{Conclusion}

The 2014-15 Bárðarbunga rifting event was extensively monitored, presenting a unique chance to gain insight into dike intrusion and magmatic rifting processes. We have relocated the seismicity induced by the lateral dike intrusion using cross-correlation and relative relocation. This procedure greatly improves the spatial resolution of the seismic image, collapsing the hypocenters onto linear features and revealing the small $(\sim 100 \mathrm{~m})$ scale details of the dike propagation and induced seismicity, shown in Supplementary Movie 1. The relocations highlight the complex and segmented nature of the dike propagation, with side-stepping between segments and intrusion of multiple pathways - as is often observed for frozen dikes in the field - in the search for the path of least resistance. 
In the distal section of the dike (studied here), where most dike opening was observed, regional extension over $>200$ years since last rifting introduced sufficiently high ambient differential stresses for the dike emplacement to produce large amounts of seismicity. Emplacement oblique to the spreading ridge resulted in left-lateral shear motion along the dike section, and a prevalence of left-lateral shear failure. The spatio-temporal characteristics of the induced seismicity can be directly linked in the first instance to propagation of the tip and opening of the dike, and following this - after dike opening - indicate a relationship with magma pressure changes (i.e. dike inflation/deflation), followed by a general 'post-opening' decay. We find that seismicity is induced only towards the base of the dike, where dike-imposed stresses are sufficient to induce failure of pre-existing weaknesses in the crust, with greatest opening at shallower depths (see Figure 8). It is important, therefore, to remember that induced seismicity does not represent the extent of a dike, and ought be interpreted alongside geodetic observations. However, as demonstrated here, induced seismicity provides a high-resolution, effectively 3D image of the dike, feasibly in near real-time, and as such is a vital tool for monitoring volcanic rifting events.

\section{Acknowledgments}

Seismometers were borrowed from the Natural Environment Research Council (NERC) SEIS-UK [loans 968 and 1022], with funding by research grants from the NERC and the European Community's Seventh Framework Programme [grant 308377, Project FUTUREVOLC], and graduate studentships from the NERC (NE/L002507/1). We thank our colleagues Thorbjörg Ágústsdóttir and Tim Greenfield for their contributions, and Sveinbjörn Steinbórsson and others who assisted with fieldwork in Iceland. The Icelandic Meteorological Office, Chris Bean (University College Dublin), and the British Geological Survey kindly provided additional data from seismometers in northeast Iceland, data delivery from IMO seismic database 20151001/01. The raw seismic data are archived at Cambridge University and will be available at IRIS for download from October 2019. The GISMO toolbox is freely available from https://geosciencecommunity-codes.github.io/GISMO/ and the MTfit software for moment tensor inversion is freely available from https://github.com/djpugh/MTfit. We thank W. Roger Buck and an anonymous reviewer for their constructive comments. Department of Earth Sciences, Cambridge contribution ESC.4332. 


\section{References}

Ágústsdóttir, T., Woods, J., Greenfield, T., Green, R. G., White, R. S., Winder, T., Brandsdóttir, B., Steinthórsson, S., Soosalu, H., 2016. Strike-slip faulting during the 2014 Bárdarbunga-Holuhraun dike intrusion, central Iceland. Geophysical Research Letters 43 (4), 1495-1503.

Belachew, M., Ebinger, C., Coté, D., Keir, D., Rowland, J. V., Hammond, J. O. S., Ayele, A., 2011. Comparison of dike intrusions in an incipient seafloorspreading segment in Afar, Ethiopia: Seismicity perspectives. Journal of Geophysical Research: Solid Earth 116 (B06405).

Brandsdóttir, B., 1992. Historical accounts of earthquakes associated with eruptive activity in the Askja volcanic system. Jökull 42, 1-12.

Brandsdóttir, B., Einarsson, P., 1979. Seismic activity associated with the September 1977 deflation of the Krafla central volcano in northeastern Iceland. Journal of Volcanology and Geothermal Research 6 (3), 197-212.

Caudron, C., White, R. S., Green, R. G., Woods, J., Ágústsdóttir, T., Donaldson, C., Greenfield, T., Rivalta, E., Brandsdóttir, B., 2018. Seismic amplitude ratio analysis of the 2014-2015 Bárðarbunga-Holuhraun dike propagation and eruption. Journal of Geophysical Research: Solid Earth 123, 264-276.

DeMets, C., Gordon, R. G., Argus, D. F., 2010. Geologically current plate motions. Geophysical Journal International 181 (1), 1-80.

Drew, J., White, R. S., Tilmann, F., Tarasewicz, J., 2013. Coalescence microseismic mapping. Geophysical Journal International 195 (3), 1773-1785.

Eibl, E. P. S., Bean, C. J., Jónsdóttir, I., Höskuldsson, A., Thordarson, T., Coppola, D., Witt, T., Walter, T. R., 2017. Multiple coincident eruptive seismic tremor sources during the 2014-2015 eruption at Holuhraun, Iceland. Journal of Geophysical Research: Solid Earth 122 (4), 2972-2987.

Einarsson, P., Brandsdóttir, B., 1980. Seismological evidence for lateral magma intrusion during the July 1978 deflation of the Krafla volcano in NE-Iceland 47, 160-165.

Got, J.-L., Fréchet, J., Klein, F. W., 1994. Deep fault plane geometry inferred from multiplet relative relocation beneath the south flank of Kilauea. Journal of Geophysical Research: Solid Earth 99 (B8), 15375-15386.

Green, R. G., Greenfield, T., White, R. S., 2015. Triggered earthquakes suppressed by an evolving stress shadow from a propagating dyke. Nature Geoscience $8,629-632$.

Greenfield, T., White, R. S., Ágústsdóttir, T., Winder, T. W., 2018. Seismicity of the Askja and Bardarbunga volcanic systems of Iceland, 2009-2015. Journal of Volcanology and Geothermal Research, In press.

URL https://doi.org/10.1016/j.jvolgeores.2018.08.010 
Greenfield, T., White, R. S., Roecker, S., 2016. The magmatic plumbing system of the Askja central volcano, Iceland, as imaged by seismic tomography. Journal of Geophysical Research: Solid Earth 121 (10), 7211-7229.

Gudmundsson, M. T., Jónsdóttir, K., Hooper, A., Holohan, E. P., Halldórsson, S. A., Ófeigsson, B. G., Cesca, S., Vogfjörd, K. S., Sigmundsson, F., Högnadóttir, T., Einarsson, P., Sigmarsson, O., Jarosch, A. H., Jónasson, K., Magnússon, E., Hreinsdóttir, S., Bagnardi, M., Parks, M. M., Hjörleifsdóttir, V., Pálsson, F., Walter, T. R., Schöpfer, M. P. J., Heimann, S., Reynolds, H. I., Dumont, S., Bali, E., Gudfinnsson, G. H., Dahm, T., Roberts, M. J., Hensch, M., Belart, J. M. C., Spaans, K., Jakobsson, S., Gudmundsson, G. B., Fridriksdóttir, H. M., Drouin, V., Dürig, T., Adalgeirsdóttir, G., Riishuus, M. S., Pedersen, G. B. M., van Boeckel, T., Oddsson, B., Pfeffer, M. A., Barsotti, S., Bergsson, B., Donovan, A., Burton, M. R., Aiuppa, A., 2016. Gradual caldera collapse at Bárdarbunga volcano, Iceland, regulated by lateral magma outflow. Science 353 (6296).

Gudmundsson, M. T., Sigmundsson, F., Björnsson, H., 1997. Ice-volcano interaction of the 1996 Gjálp subglacial eruption, Vatnajökull, Iceland. Nature $389,954-957$.

Hartley, M. E., Bali, E., Maclennan, J., Neave, D. A., Halldórsson, S. A., 2018. Melt inclusion constraints on petrogenesis of the 2014-2015 Holuhraun eruption, Iceland. Contributions to Mineralogy and Petrology 173 (2), 10.

Hartley, M. E., Thordarson, T., 2013. The 1874-1876 volcano-tectonic episode at Askja, North Iceland: Lateral flow revisited. Geochemistry, Geophysics, Geosystems 14 (7), 2286-2309.

Hayashi, Y., Morita, Y., 2003. An image of a magma intrusion process inferred from precise hypocentral migrations of the earthquake swarm east of the Izu Peninsula. Geophysical Journal International 153 (1), 159-174.

Heimisson, E. R., Hooper, A., Sigmundsson, F., 2015. Forecasting the path of a laterally propagating dike. Journal of Geophysical Research: Solid Earth $120(12), 8774-8792$.

Hjartardóttir, A. R., Einarsson, P., Gudmundsson, M. T., Högnadóttir, T., 2016. Fracture movements and graben subsidence during the 2014 Bárdarbunga dike intrusion in Iceland. Journal of Volcanology and Geothermal Research $310,242-252$.

Hollingsworth, J., Leprince, S., Ayoub, F., Avouac, J.-P., 2013. New constraints on dike injection and fault slip during the 1975-1984 Krafla rift crisis, NE Iceland. Journal of Geophysical Research: Solid Earth 118 (7), 3707-3727.

Icelandic Meteorological Office, 2014. Bárdarbunga and Holuhraun - overview. http://en.vedur.is/earthquakes-and-volcanism/volcanic-eruptions/holuhraun/, Accessed: 14/12/2017. 
Keir, D., Hamling, I. J., Ayele, A., Calais, E., Ebinger, C., Wright, T. J., Jacques, E., Mohamed, K., Hammond, J. O. S., Belachew, M., Baker, E., Rowland, J. V., Lewi, E., Bennati, L., 2009. Evidence for focused magmatic accretion at segment centers from lateral dike injections captured beneath the Red Sea rift in Afar. Geology 37 (1), 59-62.

Key, J., White, R. S., Soosalu, H., Jakobsdóttir, S. S., 2011. Multiple melt injection along a spreading segment at Askja, Iceland. Geophysical Research Letters 38 (5).

Lomax, A., Virieux, J., Volant, P., Berge-Thierry, C., 2000. Probabilistic Earthquake Location in 3D and Layered Models. Springer Netherlands, Dordrecht, pp. 101-134.

Menke, W., Brandsdottir, B., Jakobsdottir, S., Stefansson, R., 1994. Seismic anisotropy in the crust at the Mid-Atlantic plate boundary in South-West Iceland. Geophysical Journal International 119 (3), 783-790.

Morita, Y., Nakao, S., Hayashi, Y., 2006. A quantitative approach to the dike intrusion process inferred from a joint analysis of geodetic and seismological data for the 1998 earthquake swarm off the east coast of Izu Peninsula, central japan. Journal of Geophysical Research: Solid Earth 111 (B6).

Passarelli, L., Rivalta, E., Cesca, S., Aoki, Y., 2015. Stress changes, focal mechanisms, and earthquake scaling laws for the 2000 dike at Miyakejima (Japan). Journal of Geophysical Research: Solid Earth 120 (6), 4130-4145.

Pedersen, R., Sigmundsson, F., Einarsson, P., 2007. Controlling factors on earthquake swarms associated with magmatic intrusions; constraints from Iceland. Journal of Volcanology and Geothermal Research 162 (1), 73-80.

Pugh, D. J., White, R. S., 2018. MTfit: A Bayesian approach to seismic moment tensor inversion. Seismological Research Letters 89 (4), 1507-1513.

Reyes, C. G., West, M. E., 2011. The waveform suite: A robust platform for manipulating waveforms in MATLAB. Seismological Research Letters 82 (1), 104-110.

Reynolds, H. I., Gudmundsson, M. T., Högnadóttir, T., Magnússon, E., Pálsson, F., 2017. Subglacial volcanic activity above a lateral dyke path during the 2014-2015 Bárdarbunga-Holuhraun rifting episode, Iceland. Bulletin of Volcanology 79 (6), 38.

Rivalta, E., Pascal, K., Phillips, J., Bonaccorso, A., 2013. Explosive expansion of a slowly decompressed magma analogue: Evidence for delayed bubble nucleation. Geochemistry, Geophysics, Geosystems 14 (8), 3067-3084.

Rivalta, E., Taisne, B., Bunger, A. P., Katz, R. F., 2015. A review of mechanical models of dike propagation: Schools of thought, results and future directions. Tectonophysics 638, 1-42. 
Rossi, C., Minet, C., Fritz, T., Eineder, M., Bamler, R., 2016. Temporal monitoring of subglacial volcanoes with TanDEM-X - application to the 2014-2015 eruption within the Bárdarbunga volcanic system, Iceland. Remote Sensing of Environment 181, 186-197.

Rubin, A. M., Gillard, D., 1998. Dike-induced earthquakes: Theoretical considerations. Journal of Geophysical Research: Solid Earth 103 (B5), 10017 10030.

Rubin, A. M., Gillard, D., Got, J.-L., 1998. A reinterpretation of seismicity associated with the January 1983 dike intrusion at Kilauea Volcano, Hawaii. Journal of Geophysical Research: Solid Earth 103 (B5), 10003-10015.

Ruch, J., Wang, T., Xu, W., Hensch, M., Jónsson, S., 2016. Oblique rift opening revealed by reoccurring magma injection in central Iceland. Nature Communications 7,12352 .

Segall, P., Llenos, A. L., Yun, S.-H., Bradley, A. M., Syracuse, E. M., 2013. Time-dependent dike propagation from joint inversion of seismicity and deformation data. Journal of Geophysical Research: Solid Earth 118 (11), 57855804 .

Sigmundsson, F., Hooper, A., Hreinsdóttir, S., Vogfjörd, K. S., Ófeigsson, B. G., Heimisson, E. R., Dumont, S., Parks, M., Spaans, K., Gudmundsson, G. B., Drouin, V., Árnadóttir, T., Jónsdóttir, K., Gudmundsson, M. T., Högnadóttir, T., Fridriksdóttir, H. M., Hensch, M., Einarsson, P., Magnússon, E., Samsonov, S., Brandsdóttir, B., White, R. S., Ágústsdóttir, T., Greenfield, T., Green, R. G., Hjartardóttir, A. R., Pedersen, R., Bennett, R. A., Geirsson, H., La Femina, P. C., Björnsson, H., Pálsson, F., Sturkell, E., Bean, C. J., Möllhoff, M., Braiden, A. K., Eibl, E. P. S., 2015. Segmented lateral dyke growth in a rifting event at Bárdarbunga volcanic system, Iceland. Nature 517 (7533), 191-195.

Spaans, K., Hooper, A., 2018. Insights into the stress field around Bárðarbunga volcano from the $2014 / 2015$ Holuhraun rifting event. Journal of Geophysical Research: Solid Earth 123 (4), 3238-3249.

Taisne, B., Tait, S., 2011. Effect of solidification on a propagating dike. Journal of Geophysical Research: Solid Earth 116 (B1).

Thordarson, T., Larsen, G., 2007. Volcanism in Iceland in historical time: Volcano types, eruption styles and eruptive history. Journal of Geodynamics 43 (1), 118-152.

Toda, S., Stein, R. S., Sagiya, T., 2002. Evidence from the AD 2000 Izu islands earthquake swarm that stressing rate governs seismicity. Nature 419, 58-61.

Urbani, S., Acocella, V., Rivalta, E., Corbi, F., 2017. Propagation and arrest of dikes under topography: Models applied to the 2014 Bárdarbunga (Iceland) rifting event. Geophysical Research Letters 44 (13), 6692-6701. 
Waldhauser, F., Ellsworth, W. L., 2000. A double-difference earthquake location algorithm: Method and application to the Northern Hayward Fault, California. Bulletin of the Seismological Society of America 90 (6), 1353-1368.

Woods, J., Donaldson, C., White, R. S., C., C., Brandsdóttir, B., Hudson, T. S., Ágústsdóttir, T., 2018. Long-period seismicity reveals magma pathways above a laterally propagating dyke during the 2014-15 Bárðarbunga rifting event, Iceland. Earth and Planetary Science Letters 490, 216-229.

Wright, T. J., Sigmundsson, F., Pagli, C., Belachew, M., Hamling, I. J., Brandsdóttir, B., Keir, D., Pedersen, R., Ayele, A., Ebinger, C., Einarsson, P., Lewi, E., Calais, E., 2012. Geophysical constraints on the dynamics of spreading centres from rifting episodes on land. Nature Geoscience 5, 242-250. 